

\title{
Fatos sociais como esculturas
}

\author{
Social facts as sculptures
}

\section{Ms. Tiago Guidi ${ }^{\star}$}

\section{Resumo}

O intento do presente artigo é cotejar um texto clássico da antropologia e um texto clássico da história da arte - no caso, respectivamente, Formas elementares da vida religiosa (1912), de Émile Durkheim, e NegerPlastik (1915), de Carl Einstein. Ambos os textos versam sobre uma diferença entre sagrado e profano, e, principalmente, sobre a necessidade de uma externalização do sagrado em objetos específicos, que servem não somente como representação do sagrado, mas também como sua apresentação. A abordagem durkheimiana enfatizará a transcendência do fenômeno social-religioso, enquanto a abordagem einsteiniana esmiuçará a materialidade mesma do sagrado. Tais diferenças de foco permitem traçar o contorno de duas epistemes e suas respectivas implicações teórico-metodológicas. Isto é: que perguntas faz a história da arte ao objeto sagrado, e que perguntas faz a antropologia ao objeto sagrado?

\section{Palavras chave}

Antropologia da arte. Forma. Primitivismo. Sagrado. Ritual.

\begin{abstract}
This article proposes a pairing of two classical texts - Elementary Forms of Religious Life (1912), by Émile Durkheim, and Negerplastik (1915), by Carl Einstein -, of two apparently distant disciplines anthropology and art history - in order to trace points of convergence and divergence among these two modes of knowledge. Both texts are grounded on the difference between the sacred and the profane, and describe thoroughly the process through which the sacred is necessarily externalized in an object, giving it not only a representation, but also a presence in the world of senses. The durkheimean approach will emphasize the transcendence of social-religious phenomenon, whereas the einsteinean approach will take a further look on the materiality itself of the sacred. These differences of analysis allow us to sketch the contours of two different epistemes, e their respective implications on theory and method. That is: what are the questions posed by anthropology in face of the sacred object? What are the questions posed by art history in the face of the sacred object?
\end{abstract}

\section{Keywords}

Anthropology of art. Formalism. Primitivism. Sacred. Ritual. 
O desiderato por trás do presente artigo se encontra em um esforço de aproximação entre história da arte e antropologia, ou melhor, entre textos clássicos das respectivas disciplinas - Formas elementares da vida religiosa (1912), de Émile Durkheim, e NegerPlastik (1915), de Carl Einstein. Por que comparar um texto clássico da antropologia e um texto clássico de história da arte? A que se presta a tentativa de se criar um eixo de semelhanças e diferenças entre ambos? Talvez, antes de chegar aos problemas específicos que tal aproximação traz, devêssemos abordar as condições históricas mais amplas que nos permitem cogitar essa aproximação, ou, os problemas mais amplos de ambas as disciplinas, cujos rumos recentes apontam para um apagamento estratégico de suas fronteiras disciplinares precisamente no esforço de fazer jus aos problemas que se thes apresentam os objetos de estudo. De acordo com o nosso entendimento, esses apagamentos e desafios aproximam esses saberes. Comecemos pela história da arte.

As crises epistemológicas da história da arte não se dissociam do que a obra de arte, hoje, a mais de cem anos de distância de Negerplastik, impõe como seu momento crítico. Desde a derrocada dos suportes tradicionais até os rumos recentes de uma arte cada vez mais reflexiva, as crises inauguramse vez após vez pelo fato de que as obras começam a eleger para si outras categorias de pensamento, exógenas às terminologias de descrição e análise da historiografia da arte. Vê-se 0 surgimento do artista-antropólogo (Kosuth, 1975) no curso de uma nova compreensão da arte como extensão da realidade social; do artista-etnógrafo (Foster, 1995) na esteira de debates a respeito da construção da "alteridade"; do artista-sociólogo (Bourriaud, 2009) nos caminhos e descaminhos da arte cada vez mais interessada nas relações intersubjetivas. E vê-se, assim, o exílio da moderna historiografia da arte: onda há a obra, não há história da arte; onde há história da arte, não há obra. As próprias obras de arte deslocam a história que thes informa, e atravessam limites até então imprevistos. De tal sorte que se existe a possibilidade da história da arte aproximar-se da obra e cohabitar a mesma região, ela necessariamente tem de se tornar outra.

Por sua vez, vemos cada vez mais, no torvelinho de suas viradas epistêmicas, a antropologia se aproximar de uma consciência aguda do antropocentrismo, sobretudo do platonismo ancorado na divisão mente/corpo, conceitos/coisas, sentido/referente, cultura/natureza, onde a verdadeira ação social só poderia repousar do lado dos conceitos, do sentido, e da cultura, em oposição àquele da natureza, do referente, e das coisas, que só seriam dignos de nota na medida em que fossem notações do contexto social. Ou como colocam os antropólogos sociais Hanare, Holbraad, e Wastell em um recente livro:

Ao menos desde que W.H.R. Rivers declarou em 1914 que "todo movimento de interesse" na antropologia é "para fora do físico e do material em direção ao psicológico e social", antropólogos, mesmo quando trabalhando para suplantar tais distinções, tenderam ulteriormente a reiterá-las. Oposições entre o concreto e o abstrato, o físico e o mental, o material e o social duraram portanto, tornando-se hegemônicos no sentido estrito, na medida em que até mesmo os esforços para superá-las contribuíram para sua reprodução. (Hanare; Holbraad; Wastell, 2014:1 tradução nossa') 
A retomada do conceito de fetiche (Hennion, Latour, 1993), a proposição de objetos como seres agentivos e de obras de arte como pessoas (Gell, 1994), a promoção de um pensar através das coisas (Wagner, 2001), todas essas novas formas de pensamento antropológico parecem indicar que os rumos recentes da antropologia tomam como ponto de partida os objetos encarados não como elementos condicionados por conteúdos sociais, mas parte constitutiva e condicionante destes mesmos conteúdos, em uma nova ontologia planificada, que se recusa a traçar distinções apriorísticas entre pessoas e objetos, debruçando-se sobre as possibilidades de um conceito de agência social igualmente partilhado entre humanos e não-humanos. De um ponto de vista epistemológico, hoje a antropologia, assim como a história da arte, parece chegar a si mesma no momento preciso em que toca a zona liminar do seu pensamento.

E nos parece que neste movimento da antropologia em direção às coisas (isto é, cada vez mais informada por análise de qualidades sensíveis e formais de objetos), e da história da arte em direção às pessoas (isto é, cada vez mais informada pelos aspectos sócio-relacionais em que se encontram as obras de arte), há um encontro, um breve re-alinhamento de eixos disciplinares. Ou melhor, esses apagamentos recentes das fronteiras disciplinares permitem-nos retornar às suas histórias teóricas, desta vez não mais condicionadas pela defesa das suas propriedades específicas, mas pautadas pela abertura dos seus territórios epistêmicos. Se antes a antropologia parecia privilegiar as pessoas e as relações diádicas (Radcliffe-Brown, 1952) em detrimento da análise visual dos objetos, e a história da arte parecia privilegiar a análise visual de objetos em detrimento daquela das pessoas, isso agora não nos parece mais ser o caso. Vê-se que o eixo epistemológico, a partir do qual ambos os saberes terão se dividido - de um lado, as pessoas, do outro, as coisas; de um lado, os conteúdos sociais, do outro, as qualidades estético-formais dos objetos - já não é mais suficiente para assegurar uma distância entre elas.

É assim que retornamos a Durkheim e Einstein e os aproximamos. À luz das recentes mudanças das disciplinas da antropologia e da história da arte, os dois autores parecem se aproximar em uma região de vizinhança conceitual. Se é possível colocar a história da arte e a antropologia sobre um mesmo terreno - não havendo mais uma separação categórica entre pessoas e coisas, mas sua iminente confusão -, vejamos, portanto, como os dois autores podem ser revistos sob essa perspectiva.

A preocupação de Durkheim em Formas elementares da vida religiosa é dupla: estabelecer que a realidade subjacente ao fenômeno religioso é a sociedade, mas inversamente também observar que a própria religião é protótipo do funcionamento lógico da sociedade. A vida religiosa é tornada possível pela vida social, mas, igualmente, a vida social é tornada possível pela vida religiosa. Firmam-se assim os contornos de uma idealidade cara à noção durkheimiana do processo social: 0 acontecimento primeiro da sociedade é a religião, precisamente porque esta guarda a transcendência. O fenômeno religioso em questão, tomado como grau zero da religiosidade, é o totemismo - um conjunto de crenças e ritos fundamentalmente estruturado em um objeto totêmico, uma coisa. Durkheim resolverá o problema assim: "(...) o totem é antes de tudo um símbolo, a explicação material de alguma outra coisa" (Durkheim, 2003: 210). Se há uma vida "objetual" no interior da vida social, este objeto está imediatamente subsumido pelo conteúdo social que o governa - o objeto é símbolo, momento de linguagem socialmente determinada. Vemos que, na equação entre pessoas e coisas, 
Durkheim pende para o lado das pessoas (de fato, cumpre notar que, apesar do livro ser inteiramente centrado em um fenômeno religioso que se distingue pelo seu objeto de culto, em nenhum momento Durkheim descreve ou se atenta a descrever o objeto totêmico).

A preocupação de Carl Einstein terá sido no sentido inverso. Tomando como tema de estudo esculturas e máscaras africanas, sobre as quais no começo do século XX era guardada a condenação etnocêntrica de "fetiche", Einstein estabelece um argumento artístico-formal para entender 0 uso específico desses objetos nos cultos africanos - ele dirá que, na objetualidade da escultura, na escultura enquanto conjunto imanente de qualidades visuais, estará a própria lógica do culto religioso. Isto é, o sentimento do sagrado será real, não tão somente por estar fundado na realidade sui generis da sociedade, mas também por ser tornado sensível em uma forma escultórica. $\mathrm{O}$ lado das coisas parece ser reconsiderado (de fato, se Einstein será por vezes desatento na caracterização etnográfica das religiões africanas, ele não o será na proeminência atribuída às qualidades plástico-visuais dos objetos analisados).

Sabemos que os dados contextuais da escrita de Durkheim são radicalmente diferentes daqueles de Einstein, visto que aquele está às voltas com os fundamentos epistêmicos e metodológicos de uma disciplina inteira (não à toa, Formas elementares... é lido como teoria da Sociologia, Sociologia da religião, Sociologia do conhecimento, exposição do método sociológico, antropologia do ritual, etc.), enquanto este escreve o seu primeiro livro de História da Arte, sobre assuntos marginais desta mesma disciplina. Mas talvez, gostaríamos de sugerir, na liberdade de Einstein, tampouco porta-voz de um novo movimento teórico, há um apontamento possível que escapou ao Durkheim, e que nossa leitura buscará expor.

\section{A antropologia de Durkheim e o problema do totem}

É possível ler Formas elementares... tanto como um texto central ao percurso teórico de Durkheim quanto como um texto periférico. Central, porque leva às raias do paroxismo todos os elementos anteriormente elaborados da "sociedade" como realidade autônoma e de busca da "própria fonte da solidariedade social" (Hamnett,1984: 202). Periférico, pois se a religião era abordada anteriormente como epifenômeno, sobretudo subordinada a outros escritos sobre instituição da lei e da moralidade, agora ela torna-se elemento central para a inteligibilidade do fenômeno social enquanto tal (Weiss, 2012: 24). Isto é, a religião cessa de ser vista como modo de organização da coesão social, e passa a ser fundamento de coesão social, em cujo interior se torna inteligivel a própria transformação do agrupamento em grupo, da multiplicidade em unidade, da sociedade em "Sociedade".

Com efeito, no clássico livro de 1912, Émile Durkheim propõe uma genealogia sociológica da religião, que, ao ser levada a cabo, mostra-se como uma genealogia religiosa da sociedade. Isto é, não somente a religião seria um fenômeno eminentemente social, mas a própria sociedade se originaria do funcionamento lógico das operações religiosas em torno do sagrado. Empregando uma ampla gama de dados etnográficos coletados à época e concentrando-se no totemismo como forma basilar da vida religiosa, Durkheim investigará como a consciência coletiva se apresenta na sua manifestação primeva não como separação entre indivíduo e coletividade, mas como separação entre sagrado e profano. A religião seria imediatamente social para uma sociedade imediatamente religiosa, havendo 
uma dupla origem - a origem social da religião consubstanciada à origem religiosa da sociedade cuja força dar-se-ia precisamente na indistinção entre sagrado e coletivo, ou como ele coloca: "Se o totem é a um só tempo símbolo do deus e do clã, não é porque o deus e a sociedade não são um só?" (1912: 295).

Desde o livro Da divisão do trabalho social, de 1893, a empreitada teórica de Durkheim se caracterizara como uma crítica à explicação individualista da constituição da ordem social, sobretudo no conceito spenceriano de um acordo espontâneo de interesses individuais baseado em um modelo liberal. Contrário à proposição de Spencer (1820-1903) de fatos sociais como produtos emergentes das interações individuais, Durkheim introduz fatos sociais como anteriores e exteriores aos indivíduos:

Não devemos, como faz Spencer, apresentar a vida social como resultante de naturezas individuais somente, uma vez que, pelo contrário, estas surgem daquela (Durkheim, 1997:186) [...] membros da sociedade só podem ser dominados por uma força que thes é superior e há somente uma força que possui essa qualidade: aquela do grupo social. (Ibidem:143, tradução nossa) ${ }^{2}$

Em As formas elementares... completa-se o círculo dessa jornada intelectual, acrescendo à crítica original a ênfase na insuficiência de uma explicação puramente racionalista acerca da origem da sociedade, ou seja, uma concepção de sociedade baseada no contrato racionalmente formalizado. Outrossim, colocando nos termos globais de um método e teoria sociológicos, a sociedade não poderia ser concebida como meio utilitário para a realização de fins individuais, tributária ora de um acordo entre consciências individuais (individualismo-voluntarismo), ora de uma perseguição racional de interesses (contratualismo-racionalismo). A sociedade é uma realidade autônoma que agiria sobre os indivíduos.

Estão firmados aí os dois pilares da teoria durkheimiana: a unidade da vida social seria emanada do supra-individual e do não-racional, daí a importância do conceito de sagrado, realidade sui generis que excederia as consciências individuais e seria indescritível em termos puramente racionais (embora estivessem nela as raízes das categorias de entendimento). Contudo, o que poderia ser esses dois significantes - o supra-individual e o não-racional - para o significado de sagrado, além simplesmente de serem negações de modelos sociológicos prévios?

Em Formas elementares da vida religiosa, o sagrado originar-se-ia da efervescência coletiva e da exaltação não-racional ("Portanto, é nesses meios sociais efervescentes e dessa efervescência mesma que parece ter nascido a ideia religiosa" [2003, 225]), e deveria se externalizar em objetos específicos, os símbolos ("Sem símbolos os sentimentos sociais não poderiam ter senão uma existência precária" [Ibidem, 226]), que dariam ao sentimento coletivo uma materialidade e uma exterioridade supra-individual. 0 símbolo exemplar seria o objeto totêmico, cuja razão de existência seria devolver à sociedade a imagem da sua consistência. Mas vejamos melhor como se dá a passagem de um ao outro, da efervescência confusa da coletividade ao símbolo material do totem. 


\section{0 problema do totem}

Durkheim começa por localizar a origem sociológica do sagrado em uma origem psicológica do fato social. Isto é, o sagrado não é simplesmente um conjunto de representações conscientes, mas sobretudo uma passagem do mundano para o extra-mundano, da multiplicidade caótica para a coletividade coesa, na forma de celebração que afeta e move o pathos dos indivíduos:

A vida das sociedades australianas passa alternadamente por duas fases diferentes. Ora a população dispersa em pequenos grupos que se ocupam, independentemente uns dos outros, de suas tarefas; cada família vive então à parte, caçando, pescando, tentando, enfim, obter o alimento indispensável por todos os meios disponíveis. Ora, ao contrário, a população se concentra e se condensa por um tempo que varia de vários dias a vários meses, em pontos determinados. Essa concentração ocorre quando um clã ou uma parte da tribo são convocados em suas assembléias, celebrando-se nessa ocasião uma cerimônia religiosa ou realizando-se o que é chamado, na linguagem usual da etnografia, um corrobort ([1912] 2003: 221)

Vemos mais à frente Durkheim explicitar o componente patético da aglomeração:

Ora, o simples fato da aglomeração age como um excitante excepcionalmente poderoso. Uma vez reunidos os indivíduos, sua aproximação libera uma espécie de eletricidade que os transporta rapidamente a um grau extraordinário de exaltação. Cada sentimento expresso vem repercutir, sem resistência, em todas as consciências largamente abertas às impressões exteriores. (...) As paixões desencadeadas são de tal impetuosidade que não se deixam conter por nada (Ibidem: 222).

Portanto, é nesses meios sociais efervescentes e dessa efervescência mesma que parece ter nascido a ideia religiosa" (Ibidem: 225).

Está firmada aí a equação primordial, a partir da qual Durkheim conceberá a um só tempo a gênese sociológica da religião e a gênese religiosa da sociedade na esfera do sagrado, ou melhor, a partir da qual Durkheim estabelecerá uma equivalência absoluta entre fato social e fato religioso: há na aglomeração entre indivíduos uma efervescência coletiva, que se traduz como a experiência de uma força puramente transcendente, cujo aspecto teórico se revela ao sociólogo como "fato social", e cujo aspecto vivencial se revela ao crente como "fato religioso". Em outras palavras, a aglomeração é 0 primeiro momento não-racional e pático do fato social-religioso, a sua primeira emergência: a sociedade experimenta a si mesma como sagrada, pois ela sente a força de um momento singular de efervescência.

Mas se segue uma dialética, sem a qual o sublime oferecido pela excitação coletiva não consegue durar e plenamente existir. A pura transcendência e incorporalidade que a aglomeração acarreta é um momento fugidio e lábil, que não se sustenta em si mesmo - ele deve, portanto, se materializar e se corporificar em um símbolo, um objeto, para poder ser plenamente vivido:

Pois não poderíamos considerar numa entidade abstrata, que só representamos laboriosamente e com uma noção confusa, a origem dos sentimentos fortes que experimentamos. Não podemos explicá-los a nós mesmos senão relacionando-os a um objeto concreto cuja realidade sentimos vivamente (Ibidem: 227). 
Tudo o que ele (o primitivo) sente é que ele é erguido acima de si mesmo e que vive uma vida diferente do comum. Entretanto, é preciso que ele relacione essas sensações a algum objeto exterior (totem) como à causa delas (Ibidem: 228).

De fato, essa dialética entre a pura transcendência, ocasionada pela aglomeração, e a corporificação, tornada possível pelo símbolo totêmico, não vem destituída de um juízo de valor. De acordo com Durkheim, o primitivo confeccionará para si um totem por carecer de capacidades intelectivas e de um conceito de "sociedade", por meio dos quais pudesse compreender os fenômenos em questão. Ademais, carecendo do conceito para entender o sentimento coletivo, o primitivo será vítima do fetichismo, acabando por confundir o totem por aquilo que ele simboliza, o objeto coletivo pela coletividade que representa:

Ora, o totem é a bandeira do clã. É natural, portanto, que as impressões que o clã desperta nas consciências individuais - impressões de independência e de vitalidade acrescida - se liguem muito mais à idéia do totem que à do clã, pois o clã é uma realidade demasiado complexa para que inteligências tão rudimentares possam compreendê-la claramente em sua unidade concreta. Aliás, o primitivo nem mesmo percebe que essas impressões the vêm da coletividade. Não sabe que a aproximação de um número de homens associados numa mesma vida tem por efeito liberar energias novas que transformam cada um deles (Ibidem: 229)

Vê-se a construção de Durkheim a respeito da origem da sociedade mais claramente à luz desses parágrafos. Tudo se passa como se nas sociedades australianas, voltadas para o culto totêmico, houvesse "sociedade" sem, no entanto, haver o conceito de sociedade - o primitivo é capaz de fazer sociedade, experimentá-la a partir da aglomeração originária, mas tampouco consegue conceituá-la em uma categoria de entendimento efetiva, sendo assim sequestrado a meio-caminho pela sua própria confusão mental, a qual o arremessa na prisão do objeto, fazendo-lhe acreditar que a força coletiva emana dos objetos totêmicos e não da sociedade propriamente. Ou seja, o primitivo produz a realidade sui generis da sociedade, a qual concentra e condensa as forças morais que modelarão as consciências individuais, mas a apreende sob a forma opaca do totem. Ele passa de uma experiência comum para uma existência coletiva, mas imediatamente realiza a exclusão do que criou a condição de possibilidade da passagem. Ou, como coloca o próprio Durkheim:

Podemos dizer, com efeito, que o fiel não se engana quando crê na existência de uma força moral da qual depende e da qual extrai o melhor de si: essa força existe, é a sociedade. Quando o australiano é transportado acima de si mesmo, quando sente crescer nele uma vida cuja intensidade o surpreende, ele não é vítima de uma ilusão; essa exaltação é real e é realmente 0 produto de forças exteriores e superiores ao indivíduo. Claro que ele se engana quando crê que esse aumento de vitalidade é obra de um poder com forma de animal ou de planta (o totem) (Ibidem: 234).

O totem apaga os processos sociais que dão origem à sociedade, inverte a ordem da autoconstituição coletiva, e dá fundamento ele mesmo à existência social - a sociedade primitiva sente, por fim, que sua força emana do totem e não de si própria. Contudo, ao que nos interessa, gostaríamos de sublinhar o seguinte: na análise do totemismo, Durkheim, partindo do estudo do 
sagrado, consegue evidenciar os aspectos supra-individual (exterior) e não-racional (patético) da sociedade, mas esbarra com uma materialidade incômoda, aquela do totem:

Pode-se agora compreender de que maneira o princípio totêmico e, de maneira mais geral, toda força religiosa é exterior às coisas nas quais reside. É que sua noção não é construída em absoluto com as impressões que essa coisa produz diretamente sobre nossos sentidos e sobre nosso espírito. A força religiosa não é senão o sentimento que a coletividade inspira a seus membros, mas projetado fora das consciências que 0 experimentam e objetivado. Para se objetivar, ele se fixa num objeto que, assim, se torna sagrado; mas qualquer objeto pode desempenhar esse papel (Ibidem: 238).

Lendo tal passagem, é possível até mesmo substituir um termo por outro, na medida em que religião e sociedade aí se fazem quase como intercambiáveis: "a força social (religiosa) não é senão 0 sentimento que a coletividade inspira a seus membros, mas projetado fora das consciências que 0 experimentam e objetivado". Está assim reiterada e evidenciada por Durkheim a "sociedade" como pura força moral, supra-individual e não-racional, que excede as consciências individuais num ser hiper-espiritual. Este ser desce aos corpos, mas não se reduz a eles: a sociedade explica o totem, mas não é implicada por ele. "Qualquer objeto pode desempenhar esse papel": isto é, qualquer objeto pode representar a sociedade, uma vez que é da sociedade que emana a força coletiva, e não do objeto.

Porém, após esse esforço hercúleo de separação e delimitação da sociedade na sua nobre transcendência, imaterial e moral, Durkheim volta mais à frente a reconsiderar a objetualidade do totem como, de certa maneira, legítima e não inteiramente errônea e indutora do fetiche. 0 totem, ou emblema do clã, não é somente representação da força transcendente do sagrado e, portanto, da sociedade, ele também é catalisador desta mesma força:

Que um emblema seja, para toda espécie de grupo, um útil foco de congraçamento, é algo que nem precisa demonstrar. Ao exprimir a unidade social sob uma forma material, ele a torna mais sensivel a todos e, também por essa razão, o emprego dos símbolos emblemáticos deve ter se generalizado rapidamente assim que sua idéia surgiu. Mas, além disso, essa ideia deve ter brotado espontaneamente das condições da vida em comum; pois o emblema não é apenas um procedimento cômodo que torna mais claro 0 sentimento que a sociedade tem de si; ele serve para produzir esse sentimento, ele próprio é um elemento constitutivo deste (Ibidem: 240).

Como, portanto, os totens, que em um primeiro momento eram o signo do desvirtuamento do sagrado, podem adquirir a extrema dignidade de constituir, e não perverter, o sentimento que a sociedade faz de si mesma? Em um longo parágrafo Durkheim deixa claro como a materialidade do emblema totêmico pode servir não somente como desvio da coletividade, mas como catalisador da própria experiência coletiva:

Aliás, sem símbolos, os sentimentos sociais não poderiam ter senão uma existência precária. Muito fortes enquanto os homens estão reunidos e se influenciam reciprocamente, eles não subsistem quando a reunião termina, a não ser na forma de lembranças que, se forem abandonadas a si mesmas, irão se apagando cada vez mais; pois, como nesse momento o grupo não está mais presente e atuante, os 
temperamentos individuais retomam facilmente o comando. As paixões violentas que se desencadearam no seio de uma multidão refluem e se extinguem assim que ela se dissolve, e os indivíduos se perguntam com espanto como puderam se arrebatar a tal ponto fora de seu caráter. Mas se os movimentos pelos quais esses sentimentos são expressos vêm se inscrever em coisas que duram, eles próprios se tornam duradouros (Ibidem: 240, grifo nosso).

O símbolo totêmico é assim, para além do engano, o meio pelo qual a própria coletividade dá a si mesma consistência. A substancialidade do totem dá à coletividade a qualidade material que the falta: o emblema totêmico, ao invés de ser condicionado pela consciência coletiva, a condiciona por fim, transformando uma experiência fugidia de socialização em uma experiência durável e fixa de sociedade. 0 totem, sendo substância material que permite à coletividade tornar-se ela mesma substancial, é parte intrínseca do movimento imanente da sociedade. 0 simbolismo totêmico cessa de ser mistificação errônea e passa a ser coextensivo à determinação da sociedade como tal na sua realidade sui generis: 0 totem arranca a experiência coletiva das consciências individuais e a plasma em um fragmento de realidade, que atesta e dá prova da sociedade como realidade externa aos indivíduos. Vemos que se por um lado é possível falar em uma origem religiosa da sociedade, é simultaneamente possível falar em uma origem "coisal" da sociedade. Trata-se não tanto de uma vida social das coisas, mas de uma vida "coisal" da sociedade.

Aqui, não se trata de negar a equação estruturante de Durkheim (sociedade: sagrado: idealidade), mas apontar que no instante mesmo em que Durkheim parece ser bem-sucedido na clivagem entre consciência individual e consciência coletiva, e parece evidenciar claramente 0 fato social como realidade sui generis, autônoma e auto-referida, ele a joga de novo na esfera da materialidade impura. Há o símbolo totêmico ainda, e não somente isso: o símbolo totêmico, sendo coisa maciça que dura no tempo, torna a sociedade durável e resistente. Por mais que haja a comunicação de um conteúdo coletivo na efervescência, ainda assim faz-se necessário um objeto externo, que gera uma experiência comum, e que dá à consciência coletiva a substancialidade que lhe falta. Ou melhor, a objetualidade do símbolo totêmico assegura caráter real aos fatos sociais, uma vez que lhes dá duração, fixidez, substância. Vê-se que o símbolo totêmico é não somente os fatos sociais encarnados em coisas, mas os próprios fatos sociais no seu aspecto coisal, que revela por sua vez, no limite, a origem coisal da sociedade.

É aqui onde gostariamos de chamar atenção, nessa concessão feita por Dukheim ao mundo dos objetos. Se, por um lado, o totem é a manifestação material da sociedade, por outro, ele é o elemento constitutivo sem o qual a própria sociedade não duraria e não se substancializaria: ele é simultaneamente efeito da sua sociedade e sua causa. Embora as gerações mudem, o totem permanece idêntico a si mesmo, e nesta insistência no seu próprio ser, ele revela à sociedade a fixidez que ela não possui.

Em As regras do método sociológico (1895), Durkheim aconselhava ver fatos sociais como coisas, mas cabe agora ver agora as coisas (totens) como indutoras de fatos sociais. Pois se os símbolos totêmicos não simplesmente se originam da sociedade, mas também fazem a sociedade durar, a questão seria inteiramente, a partir de um novo método sociológico, ver os totens, tanto na direção 
que parte da sociedade até eles, quanto da direção que parte deles à sociedade. Aqui se faz mister um método que partilhasse tanto a análise formal da matéria do totem (como ele dura? Como ele se faz durar? 0 que na sua substância o faz ser experienciado como durável?), quanto a análise sociológica dos fatos sociais (como a sociedade se demarca como realidade sui generis e supraindividual?). Trata-se de ver sob uma dupla lente a origem social do totem e a origem coisal da sociedade no totem e através do totem.

Evidentemente, a preocupação de Durkheim caminha no sentido de hipostasiar a realidade social como um pólo auto-referido e autônomo. A objetualidade dos totens ainda será condenada como momento menor da auto-constituição da sociedade - os totens ainda serão oriundos da confusão mental, própria de uma sociedade capaz de fazer "Sociedade", sem possuir, contudo, entendimento do que é "Sociedade". Mas há um estranho historiador da arte que três anos após a publicação de Formas elementares da vida religiosas tentará levar a cabo a possibilidade brevemente sugerida por Durkheim. Ele tentará a um só tempo analisar esculturas africanas na sua qualidade formal (portanto coisal) e no seu valor religioso (portanto social), a tal ponto que ele irá sugerir que o valor da forma e 0 valor de culto irão mutuamente se afirmar no gênero da escultura africana, pois o rigor formal da escultura será entendido como elemento chave do culto africano. Como é possível que a forma visível exprima o sagrado sem traí-lo, e não somente isso, como é possivel que a forma visível o faça durar, perenizar-se numa lógica plástica?

\section{A Antropologia de Einstein}

Vale salientar alguns pontos antes de se iniciar a exegese do texto de Einstein à luz das colocações de Durkheim. Primeiramente, Einstein jamais teve contato etnográfico com as culturas africanas cujas esculturas perscruta, e tampouco no interior do texto ele faz referência detalhada aos modos de vida correspondentes a tais formas artísticas, ou às possíveis fontes bibliográficas das suas especulações (Stroher, 2011). Também emprega um termo fortemente racializado, "Neger", para caracterizar as esculturas e máscaras africanas, e não bastasse isso, muitos dos objetos ali fotografados não são de fato originários da África (Bassani, 1998). É isso o que justifica as críticas de Michel Leiris (19011990), que trabalhou com Einstein nos anos 30 na revista Documents, quando nos diz que Negerplastik é "obra etnograficamente das mais imprecisas, mas esteticamente importante", sendo dotada de "generalidade no aspecto teórico" (Leiris, 1967: 14-16). Contudo, gostaríamos de argumentar que esses sucessivos afastamentos de Einstein em relação à antropologia e à etnografia não são gratuitos, ou meramente oriundos de uma estreiteza da visão: ele o faz na medida em que as "formas artísticas puras" (Einstein, 2018: 17) seriam paradoxalmente o caminho antropológico para dinamitar e desfazer certos postulados da tradição estética e artística européias. Se, ao perseguir tal objetivo, Einstein incorre em forte teor especulativo, que priva o livro de méritos imediatamente científicos, isso é feito a partir de uma aposta: ao nosso entendimento, Einstein abre mão de maior rigor antropológico na descrição dos cultos africanos, pois acredita que na forma e na análise formal é possível encontrar, justamente, a força antropológica de tais objetos. Assim como Durkheim especula sobre a origem da sociedade entre os "aborígenes australianos", Einstein especula sobre a origem da forma plástica entre os "africanos": e ambos o fazem, em que pesem os erros etnocêntricos, sob a atração dos ganhos epistemológicos que vislumbram na construção teórica dessas alteridades. 0 ato de construir teoricamente o "outro" - seja o africano, seja o aborígene australiano - é o mesmo que 
desfazer epistemologicamente as bases da própria identidade. Enquanto um faz por meio da "religião", o outro faz pela "arte".

De fato, olhando a trajetória biográfica do historiador da arte alemão, seria lícito apontar que o seu contato foi muito mais intenso com a arte, sobretudo aquela das vanguardas européias, do que com as instituições etnográficas da sua época. Einstein começa por fazer seu nome de escritor ao publicar o romance cubista Bebuquin oder die Dilettanten des Wunders em 1912. Nesta época, ele vive sobretudo de críticas que cobriam as produções artísticas contemporâneas. A partir de 1913, começa a se concentrar exclusivamente em crítica de arte, simultaneamente à aparição das primeiras referências conhecidas sobre arte africana. Em agosto de 1913, ele escreve ao diretor do departamento de Antropologia do Museum für Völkerkunde de Berlin solicitando ajuda (sem obter resposta). A finalidade da carta era propor a publicação de um suplemento especial da revista Der Merker, dedicado exclusivamente a esculturas negras e obras mexicanas. Em agosto de 1914, ele se alista voluntariamente no conflito mundial em curso. Em novembro é ferido gravemente na cabeça e é internado em um hospital militar de Berlim. Após retomar o seu trabalho na Alsácia, ele é transferido para a seção colonial da administração civil do Governo Geral de Bruxelas. Lá, tem acesso a uma das melhores bibliotecas do mundo sobre África, particularmente sobre arte e cultura da África central. Trata-se da biblioteca do Museu do Congo na cidade de Tervuren. O livro que publica em 1915, NegerPlastik, emerge deste contato. Não sabemos se na biblioteca havia um exemplar de Formas elementares da vida religiosa, mas Einstein, analogamente a Durkheim, parte de uma divisão radical entre sagrado e profano e, mais profundamente, na necessidade de exteriorização do sagrado em objetos - no caso de Einstein, esculturas e máscaras africanas, entendidas a partir de sua forma plástica.

Ora, Einstein é um historiador da arte formalista, o que significa dizer que a análise formal não the é somente análise da imagem nas suas unidades visuais mínimas, mas, sobretudo, leitura de elementos da visão. Isto é, a partir dos aspectos formais da obra, revelam-se a um só tempo as propriedades intrínsecas da imagem enquanto objeto e as propriedades extrínsecas da imagem enquanto sujeito: "forma" significa tanto a forma do objeto quanto a forma da experiência que the corrobora. É sob essa moldura analítica que se dão os escritos de Einstein em Negerplastik, pois o estudo da forma adquire aqui os contornos de relativismo na medida em que cada forma mostra também uma outra forma de experiência visual. Para Einstein, a leitura formalista das esculturas e máscaras africanas não irá se dissociar da construção de um outro conjunto de coordenadas subjetivas diante do mundo - ver a forma será ver uma outra economia psíquica do sujeito.

Antes de adentrar nas hipóteses de Einstein, retomemos alguns pontos de Durkheim. Como havíamos visto antes, o esforço de Durkheim vai no sentido oposto à infusão do metafísico no físico. Ele afirma a separação entre físico e metafísico, sublinha reiteradamente a pura causalidade social do totem, cujo fundo de realidade repousa na força anônima e impessoal da coletividade e não propriamente no objeto totêmico:

Pode-se agora compreender de que maneira o princípio totêmico e, de maneira mais geral, toda força religiosa é exterior às coisas nas quais reside. É que sua noção não é construída em absoluto com as impressões que essa coisa produz diretamente sobre 
nossos sentidos e sobre nosso espírito. A força religiosa não é senão o sentimento que a coletividade inspira a seus membros, mas projetado para fora das consciências que 0 experimentam e objetivado. Para se objetivar, ele se fixa num objeto que, assim, se torna sagrado; mas qualquer objeto pode desempenhar esse papel. (Durkheim, 2003: 238)

Ora, vê-se que a eficácia simbólica do objeto (no caso o totem) não repousa nas suas propriedades tautológicas (naquilo que objetivamente é), mas precisamente naquilo que simboliza: a coletividade. 0 totem performa a sua força arrebatadora sobre os membros da coletividade, mas isso não é mérito de qualidades visuais do objeto - pelo contrário, isso expõe a ação da consciência coletiva sobre as consciências individuais (o objeto não age sobre a coletividade, mas encarna a ação que emana da coletividade). Como coloca Durkheim, qualquer objeto poderia indexar essa força coletiva porquanto participasse da realidade supra-individual e não-racional do socius. Há uma clivagem radical entre a instância metafísica da coletividade e a sua materialização no totem, a partir da qual necessariamente se delineia o primado da primeira sobre a segunda.

Einstein reconcilia a divisão estruturante em Durkheim entre metafísico e o matérico, o incorpóreo e 0 corpóreo, numa reformulação do objeto sagrado entendido não como perversão do autêntico sentimento religioso, mas como parte constitutiva da materialização do sagrado: "O metafísico... revela a si mesmo inteiramente dentro da forma acabada e se condensa na forma com impressionante intensidade" (Einstein, 2017: 29). O metafísico está também na forma do objeto. E sua impregnação corpórea reforça e constitui o sentimento do sagrado: o corpo da escultura não perverte o metafísico, mas o constitui, visto que é momento da sua conformação ritual.

Compreende-se melhor o que está em jogo: Einstein, ao enfatizar a forma da escultura africana e, portanto, ao afirmar que a escultura possui força metafísica a partir das suas qualidades formais e visuais, afirma que o objeto sagrado não poderia ser qualquer objeto. Há algo nas qualidades intrínsecas e sensíveis do objeto escultórico africano que o abrem para a eficácia simbólica de um objeto de culto. Há algo próprio da substância escultórica, aferida na sua forma visível e experienciável, que traz à tona o seu conteúdo social e antropológico: a escultura africana radicaliza a confusão entre significante e significado, pois na própria materialidade do significante há a transcendência do significado social.

A confusão entre objeto e divindade, que Durkheim abominava como sendo fruto da percepção errônea do "primitivo", em Einstein torna-se fundante. 0 objeto não é degradação do sentimento metafísico, mas momento da sua plena realização. A forma plástica da escultura não se afasta da própria eficiência do culto: a integração entre análise formal e conteúdo antropológico torna-se completa em Negerplastik.

O que existe, portanto, na escultura africana, à altura da sua forma, que a torna capaz de eficácia simbólica ${ }^{3}$ ? Einstein começa por estabelecer uma diferença entre 0 que ele entende como "olhar africano" e o olhar ocidental:

O naturalismo óptico da arte ocidental não é a imitação de uma natureza externa; pelo contrário, a natureza que é passivamente imitada aqui é meramente a perspectiva 
vantajosa do espectador. Daí o geneticismo, o tremendo relativismo que caracteriza grande parte da nossa arte. Esta arte adaptou a si mesma ao espectador (frontalidade, imagem distante); e a produção da forma ótica final fora progressivamente confiada a um espectador participante (Einstein, 2017: 49).

A arte ocidental seria governada por um modelo óptico de perspectiva, que transformaria toda e qualquer imagem em um cálculo específico de subordinação a um sujeito individualizado e monocular. O que Einstein irá desprezar na arte ocidental, a partir da revolução trazida pelo cubismo, é o seu psicologismo, a sua concepção orientada para a fruição distante de um sujeito concebido como autosuficiente e desinteressado. 0 naturalismo e o realismo da arte ocidental seriam a manifestação acabada de uma arte feita para se cristalizar em um sujeito monocular e transparente a si mesmo, capaz de apreender o mundo soberanamente. Em contraste, a arte africana "forma uma equação em que as sensações naturalísticas de movimento, e portanto de massa, são completamente absorvidas e... a sua sucessiva diferenciação... convertida em uma ordem formal" (Einstein, 2017:51).

Isto é, a escultura africana, ao invés de se psicologizar e, portanto, se adequar à imagem mental de um sujeito soberano, segue uma lógica intrínseca à própria escultura. Há aqui uma radical lógica do campo sensível, que não se dobra a uma lógica subjetiva, ou como coloca o própria Einstein: "As partes (da escultura) estão alinhadas, não de acordo com o ponto de vista do espectador, mas a partir de si mesmas" (Ibidem: 134). Isto é, as esculturas africanas na sua cristalização substancial não se sujeitam a um só ponto de vista, mas são a condensação de vários. Ou, novamente, como coloca Einstein:

todas as partes da composição, incluindo aquelas que não são imediatamente visíveis estão reunidas com as partes visíveis em uma forma total, a qual em um só ato de visão define o espectador e corresponde a uma experiência tridimensional fixa (Einstein, 2017: 49)

A escultura africana é "fora de proporção" (Ibidem: 53), pois a sua forma prevê que ela seja vista a partir de múltiplos pontos de vista - isto é, o seu rigor formal trabalha pelo desvencilhamento da escultura de um só ponto de vista subjetivo, posto que todas as partes, absorvidas ou não pelo ponto de vista individual, concorrem para formar uma totalidade visual. Ela é intrinsecamente coletiva, visto que não é definida por um espectador, mas define múltiplos. 0 seu caráter anti-mimético, antipsicológico, estabelece a sua radical exterioridade a uma consciência individual, e a posiciona em uma esfera externa à captura pelo ponto de vista.

Em outras palavras, o valor de culto atribuído anteriormente por Durkheim ao totem, retido entre 0 sentimento do sagrado e sua perversão no objeto, retorna em Einstein sob aspecto redentor, visto que o objeto não perverte a força coletiva ou a força divina, mas a multiplica na sua própria forma: "Ela (a escultura) não significa nada, ela não é símbolo; ele é o deus que conserva a sua realidade mítica fechada, na qual ela inclui o adorador, o transforma também em ser mítico e abole sua existência humana" (Einstein, 2017: 17). Se em Durkheim o símbolo totêmico seria o meio de fazer o sentimento religioso-coletivo durar, sem por isso ser-lhe a causa, em Einstein a escultura religiosa é intrínseca à própria constituição do fenômeno religioso-coletivo, nas suas plenas qualidades formais e sensíveis. 
Observando a "máscara africana", no último capítulo de Negerplastik, Einstein aponta:

A máscara possui significado somente na medida em que é inumana, impessoal, o que quer dizer construtiva, livre da experiência vivida do indivíduo; talvez o negro honre a máscara como deidade até mesmo quando não a veste. Eu gostaria de chamar a máscara de "êxtase fixo", e talvez também um meio que em qualquer momento poderia servir como estimulante ao êxtase, porque a face do poder venerado está fixada ali (Einstein, 2017: 41).

Não por acaso, encontramos a conjunção entre êxtase e forma. "Êxtase" na sua acepção grega significa "sair de si mesmo", e nisso está evidente a equação promulgada por Einstein - a forma na sua lógica interna teria a força de despersonalização radical e extática, que asseguraria, portanto, 0 seu feixe coletivo e religioso. Vê-se que se Durkheim havia sugerido que o objeto poderia dar guarida e sustento à "efervescência coletiva", agora em Einstein esta possibilidade é levada às raias do paroxismo uma vez que a escultura e a máscara nas suas formas asseguram o momento "extático" e 0 ato de "sair de si mesmo". Isto é, elas desindividualizam o sujeito e o aproximam da experiência religiosa-coletiva. Em Formas elementares da vida religiosa, havia a díade implícita da coletividade o supra-individual (transcendência), e o coisal (objeto totêmico) - com a supressão do último elemento. Agora essa díade torna-se plenamente explícita, visto que a coisa é plenamente detentora de agência social na sua lógica sensível, que não desvirtua a aparição do sentimento coletivo ao materializá-lo, mas o abre, a partir da esfera formal, à concreção plena.

O método de análise formal empregado por Einstein, à cata das soluções intrínsecas da visualidade e dos ajustes dos pontos de vista na matéria plástica, acaba por se revelar inversamente em um método de análise antropológico-sociológico da forma. Passamos de um conjunto de formas elementares da vida religiosa para um conjunto de formas escultóricas da vida religiosa. A força formal da escultura $e$ máscara africanas torna-se a força do seu valor de culto. Ela é transcendente em virtude da forma:

A obra, fruto do trabalho do artista, permanece independente, transcendente e desprovida de qualquer ligação. A essa transcendência corresponde uma visão do espaço que exclui toda função do espectador; é preciso oferecer e garantir um espaço do qual se retiraram todos os recursos, um espaço total e não fragmentado (Einstein, 2017: 41).

A aparição visível da forma não somente implica o transcendente, mas o explicita na medida em que a forma se torna fonte ela própria do sentimento do transcendente enquanto tal. Está precisamente aqui a radicalidade do pensamento de Einstein - 0 objeto sagrado não somente representa a experiência coletiva, mas a apresenta, ou melhor, a presentifica: não somente significa sociedade, mas faz sociedade, graças à sua forma que nega intrinsecamente o ponto de vista individual. Não somente representa 0 transcendente, mas 0 faz. Se esta possibilidade estava sugerida em Durkheim, numa breve brecha por onde a origem coisal da sociedade emergiu, ela aqui é salientada e convertida plenamente em vivência.

Na conclusão de Formas elementares da vida religiosa, Durkheim nos diz: "Ora, a vida lógica supõe evidentemente que o homem sabe, pelo menos confusamente, que existe uma verdade distinta das aparências sensíveis" e posteriormente conclui: "É sob a forma de pensamento coletivo que o 
pensamento impessoal (lógico) se revelou à humanidade pela primeira vez" (Durkheim, 1988: 176). No entanto, gostaríamos de argumentar, junto a Einstein, que há uma lógica das qualidades sensíveis, lógica que no interior da sua conformação faz emanar uma impessoalidade e, portanto, "sociedade" como quer Durkheim. A objetificação da sociedade no totem, ou escultura, ou máscara, não é deturpação da sociedade, mas momento da sua plena presença a si mesma sob forma sensível. Em Einstein, o dito "primitivo" não objetifica a sociedade por carecer de uma noção que pudesse conceber conceitualmente e logicamente a sociedade: pelo contrário, ele vai a fundo no seio de uma lógica de qualidades sensiveis, cujo horizonte é positivar a sociedade a si mesma em uma forma de experiência que ao negar o ponto de vista individual, afirma o coletivo. 0 objeto sagrado, para além de epifenômeno da sociedade, torna-se aqui um substrato existencial da sociedade. Ele não só representa a sociedade, como também faz sociedade. Não por acaso no capítulo derradeiro de Negerplastik, "Máscaras e práticas similares", Einstein estabelece com mais ênfase a correlação entre forma e sociedade: ao vestir a máscara, o fiel encarna a forma, e ao encarná-la faz-se outro - e, portanto, cria sociedade.

É em relação à máscara que o europeu, versado na psicologia e na arte do teatro, melhor compreende o sentimento. $O$ ser humano sempre se transforma um pouco, esforçando-se, entretanto, por conservar sua identidade. $O$ europeu faz precisamente desse sentimento 0 objeto de um culto quase hipertrofiado; o negro, que é menos prisioneiro do eu subjetivo e venera as forças objetivas, deve, para se afirmar ao lado delas, converter-se nessas forças, justamente quando as festeja de maneira mais fervorosa. Mediante essa metamorfose, ele estabelece um equilíbrio com a adoração que arrisca aniquilá-lo; ele reza a deus, dança em êxtase com a tribo e se transforma, por meio da máscara, nessa tribo e nesse deus (Einstein, 2015: 61).

Em linhas gerais, poderíamos colocar assim: para Einstein a forma das esculturas e das máscaras não só sofrem a ação de um conteúdo coletivo que lhes é externo, como também possuem força de ação coletiva. As formas agem. As esculturas são fatos sociais.

\section{Referências}

ALVES, J. F. O acervo como protagonista do MARGS. In: HOLTZ, Raul. Museu de Arte do Rio Grande do Sul Ado Malagoli. Catálogo Geral. Porto Alegre: MARGS, 2013.

BOURRIAUD, N. Estética relacional. São Paulo: Martins Fontes, 2009.

DURKHEIM, E. The Division of Labor in Society. New York: The Free Press. [1893] 1997.

DURKHEIM, E. The Elementary Forms of Religious Life. New York: Oxford University Press. [1912] 2001.
As regras do método sociológico. São Paulo: Martins Fontes, 1999.

As formas elementares da vida religiosa. São Paulo: Martins Fontes, 2003.

EINSTEIN, C. Negerplastik. Leipzig: Verlag der weissen Bücher, 1915. Tradução francesa de Liliane Meffre publicado em Travaux et Mémoires du Centre de Recherches Historiques sur les relations artistiques entre les cultures, fasc.1, Université de Paris 1, Paris 1976, republicado sob o título La sculpture nègre em Qu'est-ce que la sculpture moderne? Catálogo de exposição, Centre Georges 
Pompidou, Musée National d'Art Moderne, Paris, 1986.

EINSTEIN, C. Negro Sculpture. Translated by Charles W. Haxthausen and Sebastian Zeidler. October 107, Inverno 2004.

EINSTEIN, C. Negerplastik. Tradução Inês de Araújo. Organização e Introdução de Liliane Meffre. Tradução de Fernando Scheibe. Florianópolis: Ed. da UFSC, 2011.

EINSTEIN, C. Carl Einstein e a Arte da África (org. Elena O"Neill e Roberto Conduru). Rio de Janeiro: Ed. UERJ, 2017.

FOSTER, $H$. The Artist as Ethnographer?. MARCUS, G.; MYERS, F.R. (eds.). Traffic in Culture: refiguring Art and Anthropology. Los Angeles: University of California Press, 1995.

HEMNETT, I. Durkheim and Modern Sociology. Cambridge: Cambridge University Press, 1984.

GELL, A. Art and Agency: an Anthropological Theory. Oxford: Oxford University Press, 1998.

KOSUTH, J. Artist as Anthropologist [1975]. In: The Everyday: Documents of Contemporary
Art, Stephen Johnstone (ed.). Cambridge, Mass.: MIT Press, 2008.

LEIRIS, M. The Discovery of African Art in the West. In: African Art. New York: Golden Press, 1968.

LÉVI-STRAUSS, C. Antropologia estrutural, São Paulo: Ed. Ubu: 2018.

HENNION, A. ; LATOUR, B. Objet d'art, objet de science. Note sur les limites de l'antifetichisme. Paris: L'Harmattan, 1993.

RADCLIFFE-BROWN, R. Estrutura e função na sociedade primitiva. Coleção Antropologia. Petrópolis: Vozes, 1973.

MEFFRE, L. Carl Einstein 1885-1940. Itinéraires d'une pensée moderne. Paris: Presses de l'Université Paris-Sorbonne, 2002.

WAGNER, R. The Anthropology of the Subject: Holographic Worldview in New Guinea and its Meaning and Significance for the World of Anthropology. Berkeley: University of California Press, 2001.

\section{Notas}

\footnotetext{
* Mestre em Teoria e História da Arte pela Universidade de Brasília. Doutorando no Departamento de Antropologia da mesma universidade. E-mail: tchaiguidi@gmail.com. ORCID: <https://orcid.org/0000-0002-6524-7798>.

1 Original: At least since W. H. R. Rivers declared in 1914 that "the whole movement of interest" in anthropology is "away from the physical and material towards the psychological and social", anthropologists, even while working to undermine such distinctions, have tended ultimately to reiterate them. Oppositions between the concrete and the abstract, the physical and the mental, the material and the social have thus endured, becoming hegemonic in the strict sense, in that efforts to overcome them have often contributed to their reproduction

2 Original: We should not, as does Spencer, present social life as the resultant of individual natures alone, since, on the contrary, it is rather the latter that emerge from the former

Original: ...members of a society can only be dominated by a force that is superior to themselves and there is only one of these that possess this quality: that of the group

${ }^{3}$ Nós nos fiamos aqui no conceito de "eficácia simbólica" de Lévi-Strauss (2018).
}

Texto recebido em março de 2019. Aprovado em agosto de 2019. 